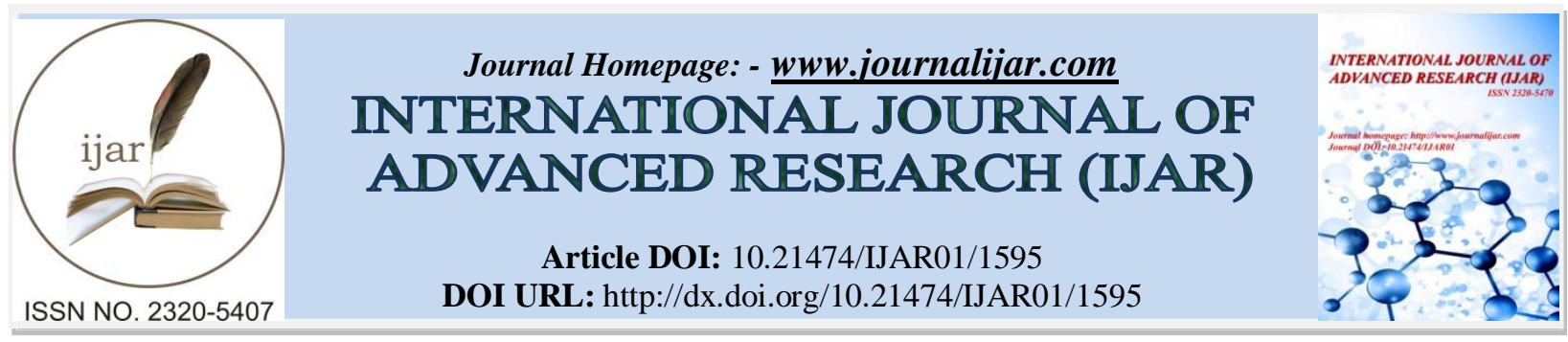

RESEARCH ARTICLE

\title{
SEMEN ABNORMALITY AND CHLAMYDIA TRACHOMATIS ANTIBODIES AMONG MALE PATIENTS ATTENDING FERTILITY CLINICS IN NNEWI, ANAMBRA STATE.
}

*Okwelogu Izunna Somadina ${ }^{1}$, Agbakoba Nneka Regina ${ }^{2}$ and Oguejiofor Chariot ${ }^{3}$.

1. Department of Parasitology and Entomology, NnamdiAzikiwe University, Awka, Anambra State, Nigeria.

2. Department of Medical Laboratory Science,NnamdiAzikiwe University, Nnewi, Anambra State, Nigeria.

3. Department of Obstetrics and Gynaecology, College of Health Sciences, NnamdiAzikiweUniversity, Nnewi Campus, Anambra State, Nigeria.

\section{Manuscript Info}

(........................

Manuscript History

Received: 12 July 2016

Final Accepted: 22 August 2016

Published: September 2016

Key words:-

Chlamydia trachomatis, Serum, Semen,

Sero-positive, Infertility.

\section{Abstract}

Against the background of increasing cases of male infertility in our community, this study was carried out to screen the serum of male patients for the presence of Chlamydia trachomatis antibodies and also analyse their semen samples for abnormalities. Five hundred (500) subjects aged between 25-49 years, were randomly recruited for the study. Four hundred (400) had infertility as their main complaint while the remaining 100 without complaint served as controls. Semen and blood samples were collected from each of the subjects. The semen samples were examined for abnormalities using Makler counting method. The blood samples were allowed to clot and the serum collected for sero-diagnosis using immunoCombChlamydia trachomatis kits (Inverness medical innovations, ORGENICS, Israel). An overall Chlamydia trachomatis sero-prevalence rate of $13.0 \%$ out of 500 patients were positive. Oligozoospermia was the highest form of abnormality recorded 49(29.3\%) among the subjects and the least was azoospermia 1(2.9\%). Oligozoospemia was more in age group 25-29 years old 17 (34.7\%). Although the prevalence of Chlamydia trachomatis antibody in this study is low, this organism may play contributory roles in infertility and so effort should be made to screen patients attending fertility clinics routinely for it.

Copy Right, IJAR, 2016,. All rights reserved.

\section{Introduction:-}

Chlamydia infection is a common sexually transmitted infection in humans caused by a bacterium, Chlamydia trachomatis. Four million cases of Chlamydia trachomatis are reported annually (WHO, 2010). The most common manifestation of male infertility is low sperm count. Possible influence of Chlamydia trachomatis infections is on semen quality (Low, 2007).Chlamydia trachomatis is a deadly silent killer, been asymptomatic during the early stage of infection and since the disease is undiscovered at the early stage and deadly, it has not only brought about the reduction in the population (Emuoyibofarheet al, 2015).

\section{Materials and methods:-}

This was a cross sectional study from subjects attending fertility clinics in Nnewi. Five hundred subjects (500) subjects were randomly selected for the study. Four hundred of them were subjects and had infertility as their main 
complaint. The remaining 100 were students who had no complaint and so were recruited as controls. The consent form was administered to subjects and questionnaires were used to gather relevant information.Ethical consideration was sought from the Ethics Committeeof Faculty of Health Sciences, NnamdiAzikiweUnversity, Nnewi Campus. All subjects provided a semen specimen by masturbation. Blood and semen specimens collected were analysedin accordance with Osazuwaet al., (2013) using immunoCombChlamydia trachomatis kits (ORGENICS, Israel).Semen samples were examined microscopically using the Makler chamber to determine the semen abnormality.

\section{Results}

Five hundred (500) subjects including control aged between 25-49 years old, were randomly recruited for the study in Nnewi, South-Eastern Nigeria. Four hundred (400) had infertility as their main complaint while the remaining 100 without complaint served as controls. An overall Chlamydia trachomatis sero-prevalence rate of $13.0 \%$ (65/500) was obtained. Sixty-five(13.0\%) out of 400 patients and 3(3.0\%) out of 100 controls were positive.

Subject of the age group 25-29 years had the highest infection rate 19.0\% followed by age group 30-34 years old, with $16.4 \%$ while those in age group $45-49$ years old had the least infection (10.6\%). The difference in age-specific prevalence ofChlamydia trachomatis among patients was statistically significant. Patients with oligozoospermia was the highest form of abnormality recorded 49(29.3\%) and the least was azoospermia 1(2.9\%). The difference between prevalence ofChlamydia trachomatis antibodies and forms of semen abnormality among patients was also statistically higher.

Table I:- Prevalence of Chlamydia trachomatis antibodies among subjects in Nnewi.

\begin{tabular}{|l|c|c|}
\hline Parameter & No. Examined & No. Positive (\%) \\
\hline Subjects & 400 & $62(15.5)$ \\
\cline { 2 - 3 } Control & 100 & $3(3.0)$ \\
\hline TOTAL & $\mathbf{5 0 0}$ & $\mathbf{6 5}(\mathbf{1 3 . 0})$ \\
\hline
\end{tabular}

Table II:- Prevalence of Chlamydiatrachomatisantibodies in relation to age groups.

\begin{tabular}{|l|c|r|}
\hline Age group (years) & No. Examined & No. Infected (\%) \\
\hline $25-29$ & 126 & $24(19.0)$ \\
\hline $30-34$ & 55 & $9(16.4)$ \\
\hline $35-39$ & 78 & $12(15.4)$ \\
\hline $40-44$ & 94 & $12(12.8)$ \\
\hline $45-49$ & 47 & $5(10.6)$ \\
\hline TOTAL & 400 & $62(15.5)$ \\
& & \\
\hline
\end{tabular}

Table III:- Distribution of different forms of semen abnormality among subjects.

\begin{tabular}{|l|c|c|}
\hline $\begin{array}{l}\text { Parameters } \\
\text { Examined }\end{array}$ & No. & No. Infected (\%) \\
\hline Oligozoospermia & 167 & $49(29.3)$ \\
\hline Azoospermia & 34 & $01(2.9)$ \\
\hline Teratozoospermia & 91 & $05(5.5)$ \\
\hline Asthenozoospermia & 108 & $07(6.5)$ \\
\hline TOTAL & 400 & $62(15.5)$ \\
\hline
\end{tabular}

\section{Discussion:-}

This study revealed prevalence rate (13.0\%) of Chlamydia trachomatis antibodies among patients with semen abnormality attending fertility clinics in Nnewi. The result in this study was lower than $28.2 \%$ in Anambra State (Anaghalu, 2006), 62.6\% (Okoror and Agbonlahor, 2012).The students selected as controls recorded only 3.0\% of the infection. The differences observed may be associated with lifestyle. For instance, lifestyle in cities such as Enugu is relatively better as compared to semi-urban area such as Nnewi. The prevalence rate of $3.0 \%$ recorded among the students (control) was also lower than 6\% recorded previously by Chukwumaet al, (2008) in NnamdiAzikiwe University, Awka. The reason could be the fact that the students are currently more aware of this infection than previously in the past.Among the age group studied, 25-29 years had the highest Chlamydia antibodies (19.0\%) followed 30-34 years old. As age increases, sexual drive decreases among couples and this could 
have led to reduction in Chlamydia infection as their age decreases. This conforms to the previous findings by Osazuwaet al, (2013). Forty-nine (29.3\%) subjects who had oligozoospermia were also infected with Chlamydia trachomatis. This could be attributed to bad attitudes towards medical check-up generally exhibited among males in this area especially the traders who are more concerned with their business.

\section{Conclusion and Recommendations:-}

This study has shown a prevalence of $13.0 \%$ of Chlamydiatrachomatis among males with semen abnormality. This is a wake-up call for intensive and regular screening of Chlamydia trachomatis infection especially among males in Nnewi. Finally, the cost of Chlamydia kits should be subsidized to enable access to it for resource limited populations and the test should be made compulsory for couples attending fertility clinics.

\section{References:-}

1. Anaghalu, I.C (2006). Prevalence of Chlamydia trachomatis among infertilemen and women in Anambra State. Department of Medical Microbiology and Parasitology, NnamdiAzikiwe University, Nnewi Campus (Postgraduate Thesis).

2. Chukwuma G.O, Emele F.E, Enweani I.B, Agbakoba N.R, Manafa P.O, Chukwuma C.M, Okwuosa M.T.B and Akujiobi C.N (2008). Relationship between Chlamydiaseropositivity and presence of symptoms of Sexually Transmitted Infections among students of NnamdiAzikiwe University, Awka. Anambra State. Journal of Biomedical Investigation, 6(2): 29-31.

3. Emuoyibofarhe O.N, Emuoyibofarhe J.O, Adeshina J, Christopher M, and Torkura K.A (2015).Developmentof the epidemiological analysis ofChlamydia

4. trachomatis among male andfemale genders in Osun State.Journal of Multidisciplinary Engineering Science andTechnology, 2: 7.

5. Low N. (2007). Screening programmes for Chlamydia infection: when will we ever learn? British Medical Journal, 334: 725-728.

6. Okoror, L.E and Agbonlahor D.E (2012). High prevalence of Chlamydia

7. trachomatis in the sperm of males withlow sperm count in Nigeria. Journal of Medical Microbiology Diagnosis, 1: 108 .

8. Osazuwa F, Osamudiamen I.A, Alakwe L., Imade P.E, Ibadin K.O and Abarare L.O

9. (2013). The prevalence of Chlamydia trachomatis among infertile males and its association with abnormal semen characteristics in Delta State. Tanzanian Journal of Health Research, 15(2): 1-5. 